\title{
Sonographic measurement of splenic length in children at Cipto Mangunkusumo Hospital
}

\author{
H F Wulandari, MD; Kemas Firman, MD
}

\begin{abstract}
Objectives The aim of this study was to determine the $10^{\text {th }}$ and $90^{\text {th }}$ percentiles and medians of normal splenic lengths of Indonesian children at Cipto Mangunkusumo Hospital by ultrasonography using a method introduced by Rosenberg et al.

Methods The maximum splenic length was obtained in longitudinal coronal plane with the splenic hilum visualized. The age of the patients were recorded. The medians and $10^{\text {th }}$ and $90^{\text {th }}$ percentiles for each age group were determined.

Results Sixty-nine boys and 46 girls were examined at our institution. The youngest subject was one month old and the oldest was 15 years old. The $10^{\text {th }}$ percentile, median, and $90^{\text {th }}$ percentile splenic length in the 1-3 months age group were $3.421 \mathrm{~cm}, 3.795$ $\mathrm{cm}$, and $4.343 \mathrm{~cm}$, respectively. In the 3-6 month age group these measurements were $3.689 \mathrm{~cm}, 4.29 \mathrm{~cm}$, and $5.094 \mathrm{~cm}$, respectively; in the 6-12 month age group $4.016 \mathrm{~cm}, 4.72 \mathrm{~cm}$, and 5.366 $\mathrm{cm}$, respectively; in the 1-2 years age group $4.558 \mathrm{~cm}, 5.04 \mathrm{~cm}$, and $5.502 \mathrm{~cm}$, respectively; in the $2-4$ year age group $5.151 \mathrm{~cm}$, $6.225 \mathrm{~cm}$, and $6.816 \mathrm{~cm}$, respectively; in the 4-6 year age group $5.774 \mathrm{~cm}, 6.415 \mathrm{~cm}$, and $7.82 \mathrm{~cm}$, respectively; in the $6-8$ year age group $6.077 \mathrm{~cm}, 7.505 \mathrm{~cm}$, and $8.228 \mathrm{~cm}$, respectively; in the $8-10$ years age group $6.354 \mathrm{~cm}, 7.77 \mathrm{~cm}$, and $8.602 \mathrm{~cm}$, respectively; in the 10-12 years age group $6.354 \mathrm{~cm}, 7.77 \mathrm{~cm}$, and $8.602 \mathrm{~cm}$, respectively; and in the 12-15 year age group $7.934 \mathrm{~cm}, 9 \mathrm{~cm}$, and $9.919 \mathrm{~cm}$, respectively. In all age groups, the $10^{\text {th }}$ percentiles, medians, and $90^{\text {th }}$ percentiles were smaller than those of American children as reported by Rosenberg et al.

Conclusion The normal splenic lengths of Indonesian children are smaller than those of American children as reported by Rosenberg et al.[Paediatr Indones 2005;45:123-126].
\end{abstract}

Keywords: splenic length, ultrasonography, children

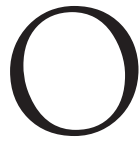

$\mathrm{n}$ physical examination, splenic size is determined by palpation and percussion. To obtain a more accurate and reliable measurement of splenic size, a few methods have been studied. Splenic size measurements using scintigraphy have been reported; however, this method exposes patients to radiation. ${ }^{1}$ Ultrasonography as a safe and practical modality to measure the spleen was used by Rosenberg et al on American children. ${ }^{2}$ As of yet, no such study has been conducted on Indonesian children. In this study, we tried to establish the normal splenic lengths of Indonesian children in Cipto Mangunkusumo Hospital, Jakarta.

\section{Methods}

This observational, descriptive study was conducted from July 2003 to July 2004. Ethical clearance was obtained from the Medical Research Ethics Committee of the Medical School, University of Indonesia. We sonographically evaluated the splenic

From the Department of Child Health, Cipto Mangunkusumo Hospital, University of Indonesia, Jakarta, Indonesia.

Reprint requests to: H F Wulandari, MD, Pediatric Imaging Division, Department of Child Health Medical School, University of Indonesia, Cipto Mangunkusumo Hospital, Jl. Salemba No. 6, Jakarta, Indonesia. Tel. 62-21-316-0621; Fax. 62-21-3907743. 
Table 1. The $10^{\text {Th }}$ Percentiles, medians, AND $90^{\text {TH }}$ Percentiles OF SPLENIC LENGTH

\begin{tabular}{llll}
\hline Age & \multicolumn{3}{c}{ Splenic length $(\mathbf{c m})$} \\
\cline { 2 - 4 } & $\mathbf{1 0}^{\text {th }}$ percentile & Median & $\mathbf{9 0}^{\text {th }}$ percentile \\
\hline 1-3 months $(n=8)$ & 3.421 & 3.795 & 4.343 \\
3-6 months $(n=7)$ & 3.689 & 4.29 & 5.094 \\
6-12 month $(n=17)$ & 4.016 & 4.72 & 5.366 \\
1-2 years $(n=13)$ & 4.558 & 5.04 & 5.502 \\
2-4 years $(n=24)$ & 5.151 & 6.225 & 6.816 \\
4-6 years $(n=12)$ & 5.774 & 6.415 & 7.82 \\
6-8 years $(n=12)$ & 6.077 & 7.505 & 8.228 \\
8-10 years $(n=4)$ & 6.354 & 7.77 & 8.602 \\
10-12 years $(n=14)$ & 7.141 & 7.85 & 9.631 \\
12-15 years $(n=4)$ & 7.934 & 9.0 & 9.919 \\
\hline
\end{tabular}

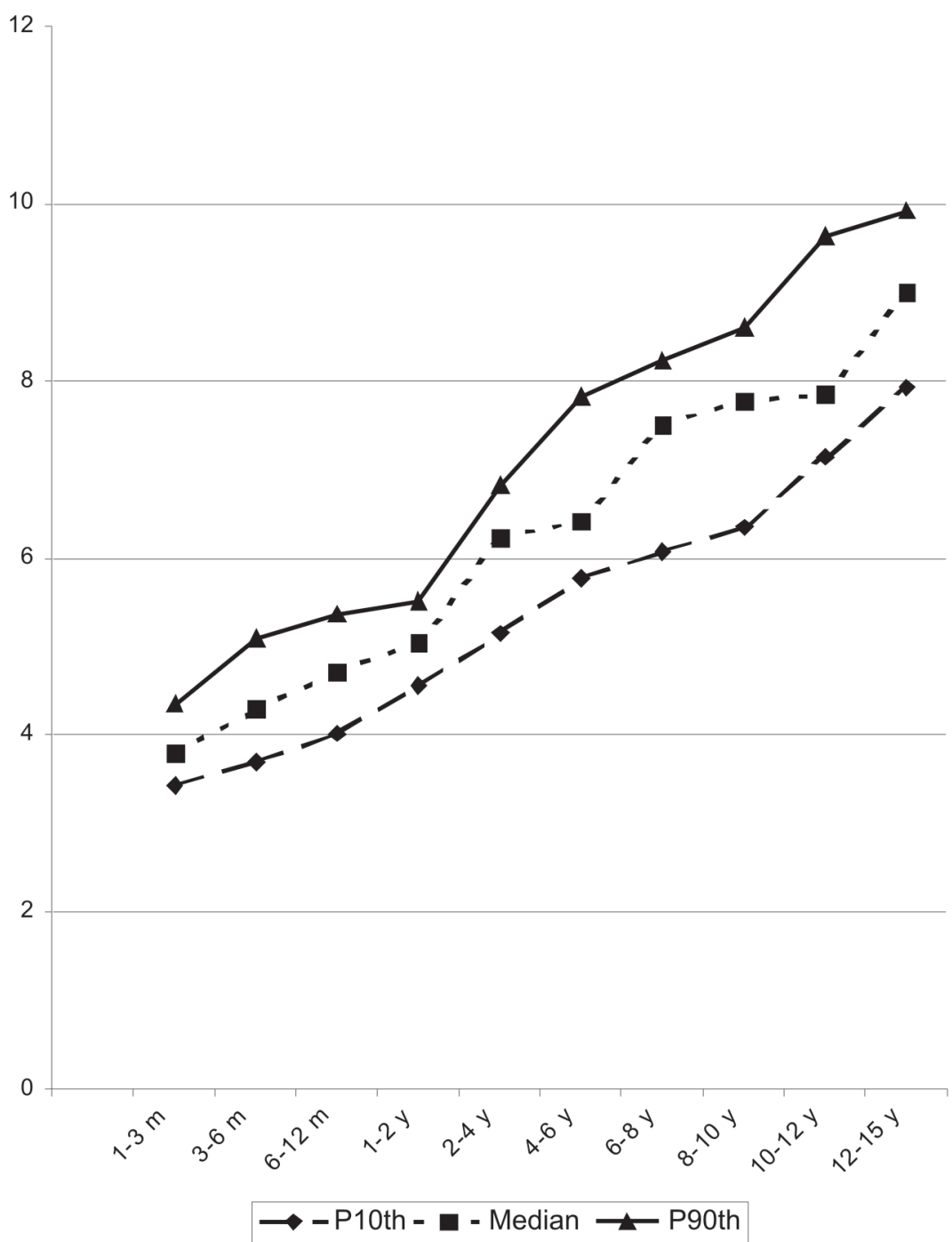

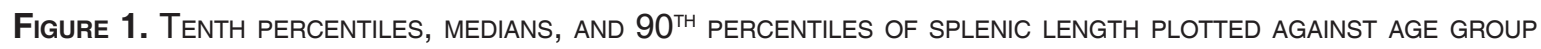


H F Wulandari et al: Sonographic measurement of splenic length in children

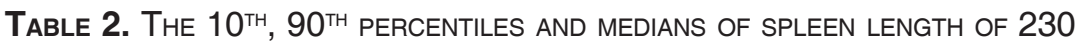
CHILDREN BY ROSENBERG ET AL ${ }^{2}$

\begin{tabular}{|c|c|c|c|c|}
\hline \multirow{2}{*}{$\begin{array}{c}\text { Age } \\
\text { (Number) }\end{array}$} & \multicolumn{4}{|c|}{ Length of Spleen $(\mathrm{cm})$} \\
\hline & 10th \%ile & Median & 90 th \%ile & $\begin{array}{l}\text { Suggested } \\
\text { Upper Limit }\end{array}$ \\
\hline o-3 months & 3.3 & 4.5 & 5.8 & 6.0 \\
\hline $\begin{array}{l}3-6 \text { months } \\
(n=13)\end{array}$ & 4.9 & 5.3 & 6.4 & 6.5 \\
\hline $\begin{array}{l}6-12 \text { months } \\
(n=17)\end{array}$ & 5.2 & 6.2 & 6.8 & 7.0 \\
\hline $\begin{array}{l}1-2 \text { years } \\
(n=12)\end{array}$ & 5.4 & 6.9 & 7.5 & 8.0 \\
\hline $\begin{array}{l}2-4 \text { years } \\
(n=24)\end{array}$ & 6.4 & 7.4 & B.6 & 9.0 \\
\hline $\begin{array}{l}4-6 \text { years } \\
(n=39)\end{array}$ & 6.9 & 7.8 & 8.8 & 9.5 \\
\hline $\begin{array}{l}6-8 \text { years } \\
(n=21)\end{array}$ & 7.0 & 8.2 & 9.6 & 10.0 \\
\hline $\begin{array}{l}8-10 \text { years } \\
(n=16)\end{array}$ & 7.9 & 9.2 & 10.5 & 11.0 \\
\hline $\begin{array}{l}10-12 \text { years } \\
(n=17)\end{array}$ & 8.6 & 9.9 & 10.9 & 11.5 \\
\hline $\begin{array}{l}12-15 \text { years } \\
(n=26) \\
15-20 \text { years } \\
(n=17)\end{array}$ & 8.7 & 10. 1 & 11.4 & 12.0 \\
\hline Female & 9.0 & 10.0 & 11.7 & 12.0 \\
\hline Male & 10.1 & 11.2 & 12.6 & 13.0 \\
\hline
\end{tabular}

lengths of children initially referred for abdominal ultrasonography for the evaluation of abdominal pain or urinary tract infection, which were unrelated to the spleen. The subjects did not suffer from any hepatic, hematologic, oncologic, or traumatic condition. Neonatal patients were not included. Patients were grouped into the age groups of 1-3 months, 3-6 months, 6-12 months, $1-2$ years, $2-4$ years, $4-6$ years, $6-8$ years, $8-10$ years, $10-12$ years, and 12-15 years. During the examination, patients were positioned supine or in a slightly right lateral decubitus position. Maximum splenic length was obtained in the longitudinal coronal plane with the splenic hilum visible. Each patient's age was recorded. The median and $10^{\text {th }}$ and $90^{\text {th }}$ percentiles for each age group were determined.

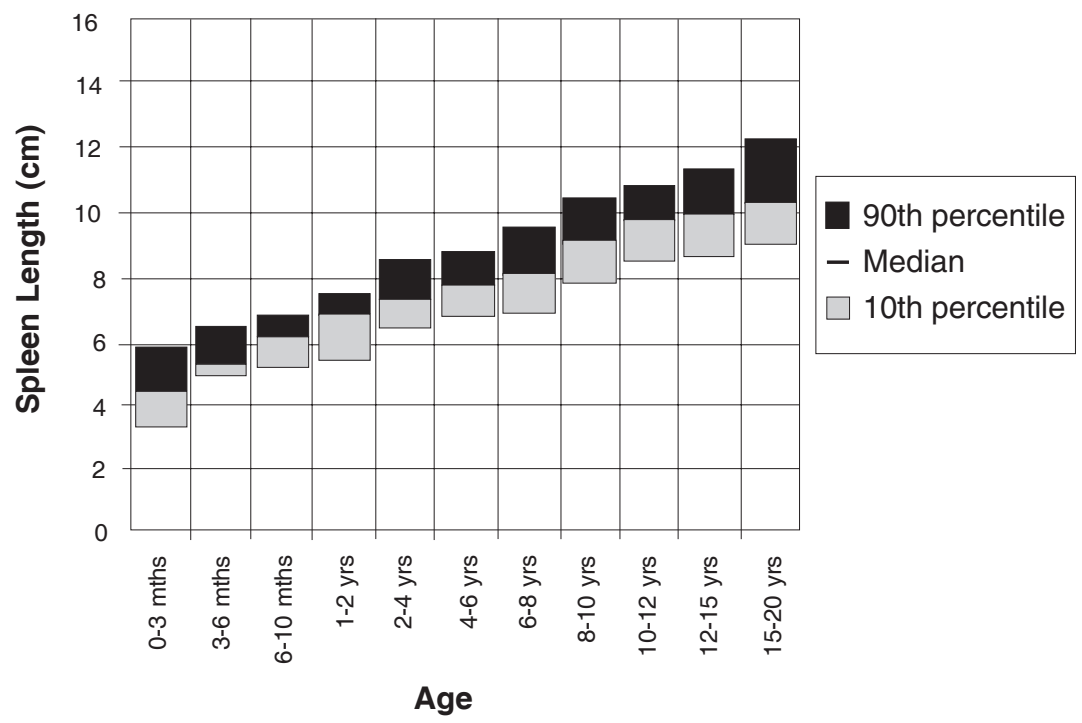

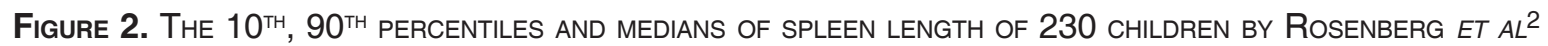




\section{Results}

One hundred and fifteen patients were studied, comprising 69 boys and 46 girls. The youngest patient was one month old and the oldest was 15 years old. Patients aged 2 to 4 years formed the largest group.

Table 1 and Figure 1 show the $10^{\text {th }}$ percentiles, medians, and $90^{\text {th }}$ percentiles of the splenic lengths of our patients in each age group. The $10^{\text {th }}$ percentile, median, and $90^{\text {th }}$ percentile splenic length in the $1-3$ month age group were $3.421 \mathrm{~cm}, 3.795 \mathrm{~cm}$, and $4.343 \mathrm{~cm}$, respectively; in the 3-6 month age group $3.689 \mathrm{~cm}, 4.29 \mathrm{~cm}$, and $5.094 \mathrm{~cm}$, respectively; in the $6-12$ month age group $4.016 \mathrm{~cm}, 4.72 \mathrm{~cm}$, and 5.366 $\mathrm{cm}$, respectively; in the 1.2 year age group $4.558 \mathrm{~cm}$, $5.04 \mathrm{~cm}$, and $5.502 \mathrm{~cm}$, respectively, in the $2-4$ year age group $5.151 \mathrm{~cm}, 6.225 \mathrm{~cm}$, and $6.816 \mathrm{~cm}$, respectively; in the $4-6$ years age group $5.774 \mathrm{~cm}, 6.415 \mathrm{~cm}$, and $7.82 \mathrm{~cm}$, respectively; in the $6-8$ year age group $6.077 \mathrm{~cm}, 7.505 \mathrm{~cm}, 8.228 \mathrm{~cm}$, respectively; in the 8 10 year age group $6.354 \mathrm{~cm}, 7.77 \mathrm{~cm}$, and $8.602 \mathrm{~cm}$, respectively; in the 10-12 year age group $6.354 \mathrm{~cm}$, $7.77 \mathrm{~cm}$, and $8.602 \mathrm{~cm}$, respectively; and in the 12 15 year age group $7.934 \mathrm{~cm}, 9 \mathrm{~cm}$, and $9.919 \mathrm{~cm}$, respectively.

\section{Discussion}

Previous studies have reported splenic measurements based on volume or mass. Splenic volume is linearly associated with age or weight, ${ }^{3}$ and a nomogram using a volume formula has been established by Dittrich et al. ${ }^{4}$ Although volume or mass measurement is a more accurate method in comparison to length measurement, Rosenberg et al found these methods to be unpractical and established a more practical method. He determined the maximum splenic length on longitudinal coronal plane sonogram with the splenic hilum visualized. He also calculated the $10^{\text {th }}$ and $90^{\text {th }}$ percentiles and medians of these maximum splenic lengths. Another previous study using ultrasound was reported by Niederau. ${ }^{5} \mathrm{He}$ found that the longitudinal and transverse diameters had poor correlation with physical data such as weight, height, and body surface area. Furthermore, as longitudinal and transverse diameters correlated well with the diagonal diameter and cross-sectional area, he concluded that these diameters were sufficient to estimate the size of the spleen. As Rosenberg's method is more practical, we attempted using it in our institution.

The results of this study shows that the $10^{\text {th }}$ percentiles, medians, and $90^{\text {th }}$ percentiles of the normal splenic lengths of our patients were smaller than the measurements of Rosenberg et $\mathrm{al}^{2}$ (Table 2 and Figure 2 ), except for the $10^{\text {th }}$ percentile in the $1-3$ month age group. This might be caused by the exclusion of neonatal patients in our study. Race and nutrition might explain the smaller splenic lengths of our patients when compared to those in Rosenberg's study. However, further study is needed to explore this possibility.

\section{References}

1. Rollo FD, Deland FH. The determination of spleen mass from radionuclide images. Radiology 1970;97:583587.

2. Rosenberg HK, Markowitz RI, Kolberg H, Park Chanhi, Hubbard, Bellah RD. Normal splenic size in infants and children: sonographic measurements. AJR 1991;157:119-121.

3. Markisz JA, Treves ST, Davis RT. Normal hepatic and splenic size in children scintigraphic determination. Pediatr Radiol 1987;17:273-276.

4. Ditttrich M, Milde S, Dinkel E, Baumann W, Weitzel D. Sonographic biometry of liver and spleen in childhood. Pediatr Radiol 1983;13:206-211.

5. Niederau C, Sonnenberg A, Mueller JE, Erckenbercht JF, Scholten T, Frithsch WP. Sonographic measurement of the normal liver, spleen, pancreas and portal vein. Radiology 1983;149:537-540. 